\section{Germany eases ban on embryonic stem-cell lines}

German researchers will be able to use hundreds more human embryonic stem-cell lines following a vote in parliament to amend the country's controversial stem-cell law.

This law had restricted researchers to working on lines created before 1 January 2002. The amendment advances the cut-off date to 1 May 2007. It will also no longer be a criminal offence for German scientists to use even newer cell lines in countries where such research is allowed.

Around 500 cell lines were created

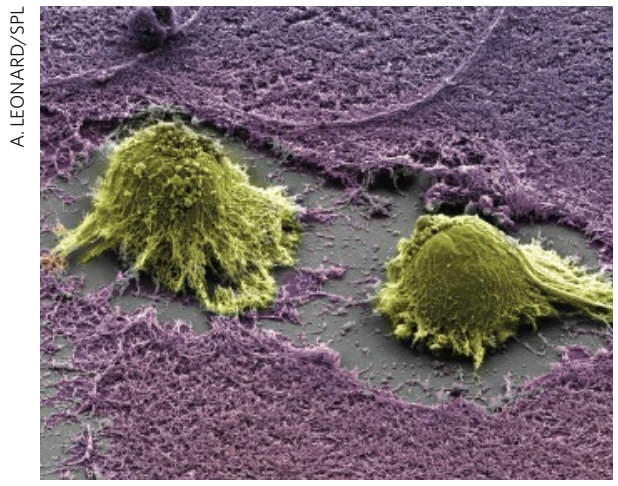

German researchers will have greater access to human embryonic stem cells after law change. between 2002 and 2007. "There are enough cell lines here of good quality that we can now use," says Oliver Brüstle, a stem-cell researcher at the University of Bonn.

Most scientists had been campaigning for a complete abandonment of the cut-off date, but the amendment explicitly states that it is a 'one-off' extension. This means Germans won't be able to work on cell lines that are now being developed for use in patients - but it is an acceptable compromise, says Brüstle.

\section{Further reports announced by climate-change panel}

The fifth Intergovernmental Panel on Climate Change (IPCC) report will be out by 2014 , IPCC chair Rajendra Pachauri announced last week in Budapest. The report from the first working group will come out in 2013, however, so that its findings can be incorporated more fully into the reports from the second and third working groups.

At its planning meeting, the IPCC also released a smaller report on the effects of climate change on water supplies worldwide. In addition, the agency plans to produce a special report on renewable energy, which is expected to be released in 2010.

\section{Evolution supporters unhappy with Florida bill}

A bill to protect teachers who present "the full range of views" on evolution is gaining ground in the Florida legislature. Critics say that if the bill is passed administrators will not be able to discipline teachers who deviate from the recently approved state education standards supporting the teaching of evolution.

"It's a really, really bad bill," says Joe Wolf, president of Florida Citizens for Science. "Any teacher who wants to can slip in a religious idea, intelligent design or the flying spaghetti monster, and they can't be fired.'

The 'academic freedom' bill borrows language from a template put together by the Discovery Institute, a Seattle-based thinktank known for its work on intelligent design. Last week, the bill cleared committees in both chambers of the Florida legislature. Final votes are expected by early May.

\section{Drug-safety agency names its first chief scientist}

The 102-year-old US Food and Drug Administration (FDA) appointed its first chief scientist last week, acting at the behest 